た。しかし, シネ撮影時の被検者の被懪線量は画質優先 の考えから議論が少ない。われわれは，現状のンステム における被検者及び術者の被曝線量を把握するため, フ アントムを用して一症例における平均被曝線量を推定し t.

[結果]当院で行われているソーンズ方式による冠動 脈造影33症例の平均被儤線量は，被検者の皮膚線量を94. $3 \mathrm{rad}$, 術種の被嚗線量を $66.5 \mathrm{mR}$ 乙推定した.今後, 被 曝軽減につなが機器が開発されるしとを期待すると共 に，われわれの現像等について研究を重ね，また術者に む，各種防謢法を含め，最小限の撮影・透視を㬇気した ().

\section{5. $\mathrm{X}$ 線 TV 装置使用時の被曝低減について}

横浜市立大学医学部病院中央放射線部 ○仙石真紀夫 ·相馬一慶・小林 修 木村秀夫 ・高橋秀一・全谷康博

医療被曝低減のため，数々の改良力゙進められているる現 在当院の X線 TV 装置更新に件い，「画像記録装置の導 入」「I·I閐接撮影時のグリット脱着機構」を組み入れた ことによって患者の被曝低減を試みたので報告する。非 熟練者汃画像記録装置を使用したことにより平均透視時 間か熟練者の画像記録装置不使用時にかなり近つき，熟 練者非熟練者による使用時不使用時の影響はTVモ二タ およびフィルムにより診断をしていた以前に比べ「見の がし」が少なくなり，透視時間が40\%程度改善された。 一方間接撮影時のグリット除去ておくて着脱が簡単て あり約20〜40\%の被曝低減がなされ，画像に関しても向 上が見られ診断上有利な結末を得るししができた。

\section{6. 撮影条件アンケートの分析（胸部）}

越谷市立病院放射線科

○堤 直葉・染谷武男

昭和 55 年増感紙検討班のアンケートをデータとして用 い胸部撮影についてのX線量を推定して，被曝し画質に ついての最適化がどのようになされているかを検討した。 X線量は電離箱により空中線量を測定したが, Al フィ ルタや入力波形により犬币に線量が異り, 今回は Kramers の理論式より求めた值を使用した．線量は全部位 比較のため撮影距離 $1 \mathrm{~m}$ にして計算した。成人胸部之小 児では管電庄が大巾に違い，乙れが小児の被曝を多くし ている。増感紙ーフィルムの感度は胸部，断層もあまり 変わらず，成人胸部が管電圧が相対的飞高い，FFD か 大でX線管焦点が画質にあまり関与せずタイマが大きな 因子となり小夰に配慮がみられる。

37.マイクロコンピータを使用したフィルム管理につ
1)

佐賀医科大学附属病院放射線部

○城戸典孝・蕰 和夫・笠原英生

放射線部て集中保管をしているフィルムの保管・検索 を效率よく，短時間に行なうために，マイクロコンビ ータ PC-8001を使用したフィルム管理システムを作成 した。処理内容は (1) ID-No. によるフィルムの検索, (2) 名前による検索，(3)使用フィルム枚数の集計, (4)フィル ム借し出し管理である.フロッピーディスク1枚に 32000 名分のデータを収納しており,ファイルの構成を王夫す るととにより検索時間も約 1 秒しなっている.

との程度のマイタロコンピーータで当施設の日常業 務に十分使用でき，省力化に役立っている。

\section{座長集約}

乙の演題群は 3 つテーマに分けることがでる.乙 の1は被儤線量の低減化を試みたものである。2は撮影 条件の検討をおこなね，3は業務管理にコンピュータを 利用したあのである。

被曝線量に関して, 冠動脈シネ撮影時, 被曝の多し乙 とを考松ら (演題34) 加測定し，皮膚表面厄 $100 \mathrm{rad}$ 近 く，術者にも多量の被曝の可能性を示している。線量測 定の例数を増し，現状を知ると共に，開発の余地加少な くなりつつある装置類と，フィルムおよび現像処理等を 総合的に再検討し，被曝低減の早期対策を必要しするこ とを示した。患者の被曝を少くするには透視等の検查所 要時間を短くするここてあり，衆知のことである。仙石 ら（演題35）は注腸透視に stop motion 像を再生し效果 を上げている。被曝線量の多少を自己部断する方法のな いとしろには群馬支部（演題29）の如く，他力らの指摘 を受けて対策を講しるるととより，低減の余地を残す施 設も多数あるようである.演者らの指摘により対応した 方法は，撮影条件，フィル多付加，増感紙，現像温度， グリットの変更等であった。しれらにより $2 / 3$ に被曝線 量を減少し得た旨の追加発表があった。

撮影条件と被曝線量の関連については多く論議されて いる.この 2 者と求められる画像との関連に関する議論 は不立分であり，結論をみていない。難問題である. 道 滕 (演題 30 ), 堤 (演題36) ら，は胸部撮影条件を姐上に のせた. 写真黒化は同程度であっても撮影条件は大巾 な分布を示して扣り，被曝線量にも大差のあることを指 摘している。撮影管電圧の選択が予稿の如〈地域的に2 つの傾向を持ち, 症例による選択のみでなく，撮影者の 被曝認識に差のある可能性をデータが示している.現実 が演題29にみられる如くであるうか。堤らは被曝線量を 